\title{
Breast reconstruction after mastectomy for breast cancer
}

\author{
Jennica Platt MD, Nancy Baxter MD PhD, Toni Zhong MD MHS
}

$\mathbf{J}$ ust as there have been improvements in the early detection and treatment of breast cancer, there have also been improvements in the techniques used for breast reconstruction after mastectomy. There are many reconstructive methods available, using either autologous tissue or implants, ${ }^{1}$ each with its unique set of indications, contraindications, advantages, disadvantages and complications (Table 1). Breast reconstruction after mastectomy is oncologically safe $\mathrm{e}^{7,8}$ and is associated with high satisfaction and improved psychosocial outcomes. ${ }^{9}$ Although the rates of major complications after immediate reconstruction (at the same time as mastectomy) are greater than after mastectomy alone, clinically significant delays in the receipt of adjuvant therapy after immediate reconstruction have not been found. ${ }^{10,11}$ Despite the potential psychological benefits of breast reconstruction, few patients who have had a mastectomy undergo breast reconstruction. ${ }^{12}$

In this review, we examine rates of breast reconstruction, discuss the factors that influence its use and review the current evidence for incorporating immediate breast reconstruction into the care of patients with early stage breast cancer.

\section{Literature review}

We searched MEDLINE (1990-June 2011, week 5) and EMBASE (1990-2011, week 26) on July 8, 2011. We used the exploded medical subject headings "mammaplasty," "mastectomy," "breast reconstruction," "socioeconomic factors," "attitude to health," "education," “decision-making," "patient preference," "physician practice variation," "health knowledge, attitudes or perceptions," "geography," "cancer stage" and "radiation or chemotherapy," with combinations of multiple keywords and synonyms such as "utilization," "barriers," "income" and "referral." Our search was limited to English-language articles. We excluded studies that investigated only ductal carcinoma in situ or had a prognostic or psychosocial primary outcome. We excluded studies from before 1990 because outdated methods of reconstruction were used before that time. In total, we identified 1482 unique articles. Two independent reviewers screened all titles, abstracts and bibliographies of the retrieved articles for relevance. There were no disagreements between reviewers. We formally reviewed 85 articles.

\section{How often is breast reconstruction performed after mastectomy?}

Canadian rates of breast reconstruction have historically been low. ${ }^{13,14}$ Two population-based studies have evaluated rates and trends (Table 2). ${ }^{13,14}$ Using population-based data, Baxter and colleagues $^{14}$ found a reconstruction rate of $7.9 \%$ in 1994/95 in Ontario, a figure that had not changed since 1984/85. Barnsley and colleagues ${ }^{13}$ examined patterns of care for breast reconstruction in Nova Scotia and found a rate of $3.8 \%$ between 1991 and 2001. There has not been a recent evaluation in Canada. We identified nine populationbased and five hospital-based studies in the United States describing the care of patients from 1985 through 2007 (Table 2). ${ }^{12,15-27}$ The rate of breast reconstruction increased from $3.4 \%$ in 1985-1990 to 42\% in 1997-2002 in a network of tertiary cancer centres. ${ }^{13,19}$

We identified six studies from other jurisdictions, four of which were English-language publications (Table 3). ${ }^{28-31}$ Australia, Denmark and England reported national rates of breast reconstruction of 9.9\% (1982-2000), 14\% (1999-2006) and $16.5 \%$ (2006-2009), respectively. ${ }^{28-30}$ A study from a single institution in Shanghai, China, reported an increase in the rate of reconstruction from $1.3 \%$ in 1990 to $5.1 \%$ in $2005 .^{31}$ These authors reported the rate of breast reconstruction in China as a proportion of all patients with breast cancer, whereas the other studies included in this
Competing interests: None declared.

This article has been peer reviewed.

\section{Correspondence to: Dr. Toni Zhong, toni.zhong@uhn.ca}

CMAJ 2011. DOI:10.1503 /cmaj.110513

\section{KEY POINTS}

- Breast reconstruction after mastectomy is an oncologically safe procedure that can improve psychosocial outcomes.

- Increased age, nonwhite ethnic background, low income and nonurban residence are associated with decreased rates of breast reconstruction.

- Physician perceptions and knowledge, as well as cancer stage, also influence the rate of this procedure.

- Mastectomy with immediate breast reconstruction should be presented to patients with in situ or early stage breast cancer as an option along with breast-conservation therapy and mastectomy alone. 
review reported the rate as a percentage of patients who had undergone mastectomy.

\section{What factors influence the use of breast reconstruction?}

We focused our review on three broad categories of factors that influence the use of breast reconstruction: patient-, cancer- and physician-related factors.

\section{Patient-related factors}

Several patient factors affect the use of breast reconstruction after mastectomy. These include age, socioeconomic status, ethnic background and location. The contribution of patient preference to these factors is unclear.

\section{Age}

The most consistent negative predictor of breast reconstruction is age greater than 50 years. ${ }^{12,13,16,17,18,20-28,30}$ This is in part because of concern about increased complication rates with age and comorbidities. In an attempt to identify predictors of breast reconstruction using the hospitalbased national sample of inpatients from 19992003, Reuben and colleagues ${ }^{27}$ found that the association between age and breast reconstruction remained significant after controlling for comorbidities. In contrast, August and colleagues ${ }^{32}$

\begin{tabular}{|c|c|c|c|c|c|c|}
\hline Type & Example & Indications & Contraindications & Advantages & Disadvantages & $\begin{array}{l}\text { Complication } \\
\text { rates }\end{array}$ \\
\hline Implant-based ${ }^{2-4}$ & $\begin{array}{l}\text { Tissue } \\
\text { expander or } \\
\text { implant } \\
\text { under the } \\
\text { pectoralis } \\
\text { major muscle }\end{array}$ & $\begin{array}{l}\text { - Small breasts with } \\
\text { minimal ptosis } \\
\text { - Insufficient donor } \\
\text { tissue (e.g., from } \\
\text { the abdomen) } \\
\text { - Patient } \\
\text { preference }\end{array}$ & $\begin{array}{l}\text { Previous or } \\
\text { anticipated } \\
\text { radiation } \\
\text { therapy }\end{array}$ & $\begin{array}{l}\text { - No morbidity at } \\
\text { the donor site } \\
\text { - Short operation, } \\
\text { admission and } \\
\text { recovery }\end{array}$ & $\begin{array}{l}\text { - Long-term } \\
\text { complications } \\
\text { related to implant } \\
\text { (e.g., capsular } \\
\text { contracture, implant } \\
\text { malposition) } \\
\text { - Multiple visits for } \\
\text { tissue expansion and } \\
\text { a second surgery to } \\
\text { replace expander } \\
\text { with implant } \\
\text { - Worse outcomes for } \\
\text { patients who require } \\
\text { radiation therapy }\end{array}$ & $\begin{array}{l}\text { - Explantation: } \\
2.7 \%-3.8 \% \\
\text { - Major } \\
\text { complications: }{ }^{*} \neq \\
4 \%-30.4 \% \\
\text { - Total } \\
\text { complications: } \\
5.8 \%-49 \%\end{array}$ \\
\hline Autologous ${ }^{2-5}$ & $\begin{array}{l}\text { - Pedicled: } \\
\text { transverse } \\
\text { rectus } \\
\text { abdominus } \\
\text { muscle } \\
\text { - Free: } \\
\text { transverse } \\
\text { rectus } \\
\text { abdominus } \\
\text { muscle, deep } \\
\text { inferior } \\
\text { epigastric } \\
\text { artery } \\
\text { perforator } \\
\text { - Other: } \\
\text { gluteal flaps, } \\
\text { thigh flaps }\end{array}$ & $\begin{array}{l}\text { - Redundant tissue } \\
\text { at the donor site } \\
\text { - Patient } \\
\text { preference }\end{array}$ & $\begin{array}{l}\text { - Severe } \\
\text { comorbidity that } \\
\text { precludes safe } \\
\text { tolerance of } \\
\text { prolonged } \\
\text { general } \\
\text { anesthetic } \\
\text { - Lack of } \\
\text { redundant } \\
\text { donor tissue }\end{array}$ & $\begin{array}{l}\text { - More natural in } \\
\text { appearance and } \\
\text { feel (v. implant) } \\
\text { - Better symmetry } \\
\text { to contralateral } \\
\text { native breast } \\
\text { - Better outcomes } \\
\text { for patients } \\
\text { requiring } \\
\text { radiation } \\
\text { therapy (v. } \\
\text { implant) }\end{array}$ & $\begin{array}{l}\text { - Longer operation, } \\
\text { admission and } \\
\text { recovery (v. implant) } \\
\text { - Increased blood loss } \\
\text { (v. implant) } \\
\text { - Complications at the } \\
\text { donor site } \\
\text { - Potential for partial } \\
\text { or total loss of tissue } \\
\text { flap }\end{array}$ & $\begin{array}{l}\text { - Total flap loss: } \\
<1-4 \% \\
\text { - Major } \\
\text { complications: } † \neq \\
7.7 \%-28.3 \% \\
\text { - Total } \\
\text { complications: } \\
22.6 \%-44.3 \%\end{array}$ \\
\hline Combination $^{6}$ & $\begin{array}{l}\text { - Pedicled } \\
\text { latissimus } \\
\text { dorsi flap } \\
\text { plus implant }\end{array}$ & $\begin{array}{l}\text { - Not a candidate } \\
\text { for autologous } \\
\text { reconstruction } \\
\text { alone (e.g., lack of } \\
\text { redundant donor } \\
\text { tissue) } \\
\text { - Previous radiation } \\
\text { therapy } \\
\text { - Patient } \\
\text { preference }\end{array}$ & $\begin{array}{l}\text { - Atrophic or } \\
\text { absent latissimus } \\
\text { dorsi muscle } \\
\text { (e.g., } \\
\text { denervation or } \\
\text { congenital } \\
\text { absence) }\end{array}$ & $\begin{array}{l}\text { - More natural } \\
\text { appearance and } \\
\text { feel than } \\
\text { implant alone } \\
\text { - Latissimus dorsi } \\
\text { muscle provides } \\
\text { additional } \\
\text { vascularity and } \\
\text { protection } \\
\text { against } \\
\text { radiation }\end{array}$ & $\begin{array}{l}\text { - Morbidity at the } \\
\text { donor site } \\
\text { - More invasive than } \\
\text { implant-based } \\
\text { surgery }\end{array}$ & $\begin{array}{l}\text { - Explantation: } \\
3.5 \% \\
\text { - Major } \\
\text { complications: } \neq \\
7 \% \\
\text { - Total } \\
\text { complications: } \\
29.8 \%\end{array}$ \\
\hline
\end{tabular}


observed fewer complications following implantbased breast reconstruction among women aged greater than 60 years compared with those less than 60. Although this finding may be related to patient selection, this study highlighted that age alone is not a contraindication for reconstruction.

\section{Socioeconomic status}

Income disparity has been linked to the different rates of breast reconstruction in the US. In a study involving 223811 patients who underwent mastectomy from 1985 to 1990 and from 1994 to 1995 , women with a family income of more than \$40 000 were twice as likely to undergo reconstruction than women whose family income was less than $\$ 40000 .{ }^{12}$ Similarly, Christian and colleagues found lower rates of reconstruction in the two lowest quartiles of median household income $(<\$ 45245) .{ }^{25}$ In Western Australia, England and Denmark, studies that used area code or level of education as proxies for social deprivation found that increased deprivation was significantly associated with lower rates of breast reconstruction. ${ }^{28-30}$ In contrast, household income did not influence the rate of breast reconstruction in Nova Scotia. ${ }^{13}$

Table 2: Canadian and US studies evaluating the rates of breast reconstruction following mastectomy

\begin{tabular}{|c|c|c|c|}
\hline Study & Study period & Database; jurisdiction & Rate of use \\
\hline \multicolumn{4}{|c|}{ Canada, population-based } \\
\hline Baxter et al. ${ }^{14}$ & $\begin{array}{l}1984-1985, \\
1995-1996\end{array}$ & $\begin{array}{l}\text { Canadian Institute for Health } \\
\text { Information; Ontario }\end{array}$ & $\begin{array}{l}7.9 \% \text { in } 1984 / 85 \text { and } 7.7 \% \text { in } \\
1995 / 96\end{array}$ \\
\hline Barnsley et al. ${ }^{13}$ & $1991-2001$ & $\begin{array}{l}\text { Medical Services Insurance and Canadian } \\
\text { Institute for Health Information; Nova } \\
\text { Scotia }\end{array}$ & $3.8 \%$ \\
\hline \multicolumn{4}{|c|}{ US, population-based } \\
\hline Polednak ${ }^{15} \dagger$ & 1988-1995 & $\begin{array}{l}\text { Surveillance, Epidemiology and End } \\
\text { Results registries; US }\end{array}$ & $\begin{array}{l}\text { Overall } 8.1 \%(4.3 \% \text { in } 1988, \\
10.8 \% \text { in } 1995)\end{array}$ \\
\hline Alderman et al. ${ }^{16} \dagger$ & 1998 & $\begin{array}{l}\text { Surveillance, Epidemiology and End } \\
\text { Results registries; US }\end{array}$ & $15 \%$ \\
\hline Polednak ${ }^{17} \dagger$ & 1988-1995 & $\begin{array}{l}\text { Connecticut Tumor Registry (part of } \\
\text { Surveillance, End Results and } \\
\text { Epidemiology); US }\end{array}$ & $9.1 \%$ in $1988,8.5 \%$ in 1995 \\
\hline Polednak ${ }^{18 *}$ & 1992-1997 & $\begin{array}{l}\text { Connecticut Tumour Registry (part of } \\
\text { Surveillance, Epidemiology and End } \\
\text { Results) and hospital discharge database; } \\
\text { US }\end{array}$ & $12.5 \%$ \\
\hline Alderman et al. ${ }^{19} \dagger$ & 1998-2002 & $\begin{array}{l}\text { Surveillance, Epidemiology and End } \\
\text { Results registries; US }\end{array}$ & $16.5 \%$ \\
\hline Joslyn ${ }^{20}$ & 1998-2000 & $\begin{array}{l}\text { Surveillance, Epidemiology and End } \\
\text { Results registries; US }\end{array}$ & $17 \% \ddagger$ \\
\hline Rosson et al. ${ }^{21} \dagger$ & 1995-2004 & Maryland hospital discharge database; US & $27.9 \%$ \\
\hline Tseng et al. ${ }^{22} \dagger$ & $2000-2006$ & $\begin{array}{l}\text { Greater Sacramento Surveillance, End } \\
\text { Results and Epidemiology; US }\end{array}$ & $20.2 \%$ \\
\hline Kruper et al. ${ }^{23 *}$ & $2003-2007$ & $\begin{array}{l}\text { Office of Statewide Health Planning and } \\
\text { Development hospital discharge } \\
\text { database, California; US }\end{array}$ & $24.8 \%$ in $2003,29.2 \%$ in 2007 \\
\hline \multicolumn{4}{|c|}{ US, hospital-based } \\
\hline Morrow et al. ${ }^{12} \dagger$ & $\begin{array}{l}\text { 1985-1990, } \\
1994-1995\end{array}$ & National Cancer Database; US & $\begin{array}{l}3.4 \% \text { in } 1985-1990,8.3 \% \text { in } \\
1994-1995\end{array}$ \\
\hline Desch et al. ${ }^{24 *}$ & 1989-1991 & $\begin{array}{l}\text { Virginia Cancer Registry (linked to Blue } \\
\text { Cross and Blue Shield); US }\end{array}$ & $16 \%$ in $1989-1991$ \\
\hline Christian et al. ${ }^{25 *}$ & 1997-2002 & $\begin{array}{l}\text { Eight national Comprehensive Cancer } \\
\text { Network centers; US }\end{array}$ & $\begin{array}{l}42 \% \text { ( } 95 \% \text { were immediate } \\
\text { breast reconstructions) }\end{array}$ \\
\hline Tseng et al. ${ }^{26} \dagger$ & 2001-2002 & $\begin{array}{l}\text { M.D. Anderson Breast Surgery database; } \\
\text { US }\end{array}$ & $37.5 \%$ \\
\hline Reuben et al. ${ }^{27} \dagger$ & $1998-2003$ & Nationwide inpatient sample; US & $23.6 \%$ \\
\hline
\end{tabular}




\section{Ethnic background}

Ethnic background has been found to influence the rate of breast reconstruction in the US, with the highest rate observed among white people. ${ }^{12,16,19,20-23,26,27,33}$ In a population-based study by Morrow and colleagues ${ }^{34}$ involving 1844 women with breast cancer, the authors found that, after controlling for age, stage of disease and level of education, black women underwent breast reconstruction less frequently than white women.

\section{Location}

Geographic variation in the rate of breast reconstruction has been found in Canadian and US studies. ${ }^{15,16,19,20,21,27}$ In Ontario, breast reconstruction occurred at twice the frequency in the Toronto area (10 reconstructions per 100 mastectomies) compared with the rest of the province (4.3 reconstructions per 100 mastectomies). ${ }^{14}$ In Nova Scotia, there was a $4.8 \%$ rate of reconstruction among women living in urban locations and a $3.7 \%$ rate among women in rural areas. ${ }^{13}$ Regional variation was also observed in England, where reconstruction rates were between $8.4 \%$ and $31.9 \%$ depending on region..$^{30}$

\section{Patient preference}

The underlying cause for the association between patient-related factors and breast reconstruction is unknown. Factors associated with decreased use have been shown not to be associated with reduced benefit from the procedure. The degree to which patient preference influences the rate of breast reconstruction is also unknown. Several surveys of patients with breast cancer who have undergone mastectomy investigated the influence of patient preferences on breast reconstruction. Older patients were found to be more likely to choose mastectomy alone than reconstruction. ${ }^{35}$ Provider bias, however, may also be a contributing factor: older and nonwhite patients were less likely than younger women and white women to receive information about breast reconstruction, ${ }^{36}$ and nonwhite women are more likely than white women to be discouraged from breast reconstruction. ${ }^{33,34}$

\section{Cancer-related factors}

The stage of cancer and adjuvant therapies, such as radiation therapy, affect the rate of reconstruction after mastectomy.

\section{Cancer stage}

The most predictive clinical factor associated with the rate of reconstruction in the US is stage of disease. Patients with ductal carcinoma in situ or American Joint Committee on Cancer stage 1 disease are more likely to undergo breast reconstruction than patients with more advanced disease. ${ }^{16-18,20,22,25}$ Canadian data are limited, but Barnsley and colleagues ${ }^{13}$ found that an advanced stage of disease was significantly associated with a lower rate of reconstruction in Nova Scotia. In a US study involving more than 200000 women with breast cancer, women with ductal carcinoma in situ or stage 1 disease made up only $42.1 \%$ of the study population but accounted for $87.6 \%$ of all breast reconstruction surgeries. ${ }^{12}$ Similar trends were identified in other US studies. ${ }^{12,16-18,20,25,26}$ Although higher stage disease is not a contraindication for breast reconstruction, women or their physicians, or both, may not perceive this restorative procedure as a high priority compared with treatment. ${ }^{37}$ Even in the context of delayed reconstruction after patients have completed treatment, the rate of breast reconstruction is still lower among those

Table 3: International studies evaluating the rate of breast reconstruction following mastectomy

\begin{tabular}{|c|c|c|c|}
\hline Study & $\begin{array}{l}\text { Study } \\
\text { period }\end{array}$ & Database; jurisdiction & Rate of use \\
\hline \multicolumn{4}{|c|}{ Population-based } \\
\hline Hall et al. ${ }^{28 *}$ & $1982-2000$ & $\begin{array}{l}\text { Western Australia Record Linkage Project; } \\
\text { Australia }\end{array}$ & $9.9 \% \dagger$ \\
\hline Hvilsom et al. ${ }^{29}$ & 1999-2006 & Danish Breast Cancer Cooperative; Denmark & $\begin{array}{l}\text { Immediate reconstruction: } 1 \% \\
\text { Delayed reconstruction: } 13 \%\end{array}$ \\
\hline Jeevan et al..$^{30}$ & 2006-2009 & $\begin{array}{l}\text { Hospital Episodes Statistics, Database of the } \\
\text { National Health Service; England }\end{array}$ & $16.5 \%$ \\
\hline \multicolumn{4}{|l|}{ Hospital-based } \\
\hline Yu et al. ${ }^{31 *}$ & 1990-2005 & $\begin{array}{l}\text { Institutional database, Shanghai Cancer } \\
\text { Hospital, Shanghai; China }\end{array}$ & $\begin{array}{l}1.3 \% \text { in } 1990-2005 \\
5.1 \% \text { in } 2005 \ddagger\end{array}$ \\
\hline
\end{tabular}


with more advanced disease. ${ }^{38}$ It is unclear whether this is because of provider bias or patient preference.

\section{Radiation therapy}

Decreased rates of breast reconstruction among patients with more aggressive disease may be confounded by factors related to cancer stage, such as the likelihood that the patient will require radiation therapy after mastectomy. ${ }^{1}$ In a population-based study involving women in Sacramento, California, the need for radiation therapy was strongly associated with decreased odds of breast reconstruction. ${ }^{22}$

\section{Physician-related factors}

The use of breast reconstruction after mastectomy can be affected by factors related to the referring physician, including practice setting and physician attitude.

\section{Physician characteristics and practice setting} In a cross-sectional survey involving 1844 patients identified between 2001 and 2003, Alderman and colleagues ${ }^{39}$ found that only $33 \%$ of patients recalled discussing breast reconstruction with their general surgeons during the surgical decision-making process. The authors also surveyed general surgeons who performed breast cancer surgeries for this cohort of patients and found that general surgeons with high rates of referral for breast reconstruction were most likely to be women, have higher volumes of breast surgery and work in cancer centres. ${ }^{37}$ Other registry studies in the US have also reported higher rates of breast reconstruction in cancer centres, as well as in urban centres with higher volumes of breast oncology surgeries. . $22,2,22,23,27,37$ and a greater concentration of surgeons performing reconstructive surgery.

\section{Knowledge and attitudes}

General surgeons with high rates of referral for breast reconstruction and those with low rates of referral have been reported to have different attitudes and perceptions about women's preferences for reconstruction. ${ }^{37}$ Surgeons with low referral rates were more likely than those with high rates to identify barriers to access to reconstruction in their practice. ${ }^{37}$ In 2002, Wanzel and colleagues performed a needs assessment of referring physicians to understand the reasons for the low rates of breast reconstruction in Canada. ${ }^{40}$ They found that $35.2 \%$ of general surgeons, $31.1 \%$ of oncologists and $45.3 \%$ of family physicians felt that inadequate knowledge about breast reconstruction negatively influenced their decisions to refer patients to plastic surgeons.

\section{What is the role of immediate breast reconstruction in the treat- ment of early stage breast cancer?}

Immediate reconstruction (at the same time as mastectomy) offers the benefits of breast reconstruction on body image and quality of life with little interruption. ${ }^{41,42}$ In the past, immediate breast reconstruction was an unpopular concept because of concerns that the surgical resection or detection of local recurrence could be compromised. ${ }^{43}$ This has not been found in practice, and these concerns are no longer barriers to immediate reconstruction. ${ }^{7.841,42}$ Box 1 presents a comparison of immediate and delayed reconstruction (any time after mastectomy) in terms of clinical and psychosocial advantages and disadvantages.

For women who have the option of breastconserving therapy or mastectomy, the selection of mastectomy with reconstruction may be preferred by those who want to avoid radiation and the stigmata associated with having a mastectomy defect. ${ }^{12}$ Because of the recommendations by the Commission on Cancer of the American College of Surgeons in 2001 to incorporate immediate reconstruction in the treatment of

\section{Box 1: Comparison of immediate and delayed breast reconstruction ${ }^{1,2,10,11}$}

Immediate breast reconstruction

- Indicated for patients with early stage breast cancer who are not expected to require radiation therapy after mastectomy

- Preserves key anatomic landmarks (e.g., inframammary fold)

- Preserves the quality and quantity of the native mastectomy skin flap when a skinsparing mastectomy is performed

- Single operation for mastectomy and first stage of reconstruction

- Increased postoperative complications compared with delayed reconstruction

- Clinically nonsignificant delay in the delivery of chemotherapy

Delayed breast reconstruction

- Indicated for patients with locally advanced breast cancer who are expected to require radiation therapy after mastectomy. Reconstruction usually takes place a minimum of six months following completion of radiation.

- Results in the loss of important anatomic landmarks

- Decreased quality and quantity of the native mastectomy skin flap

- At least two operations for mastectomy and initial stage of reconstruction 
early stage breast cancer, there has been a shift from delayed to immediate breast reconstruction in the US. ${ }^{22,23,26,27}$ Although this study reported a rate of immediate or early breast reconstruction (within four months of mastectomy) of $3.4 \%$ in 1985-1990, ${ }^{12}$ the most recent multicentre study involving the National Comprehensive Cancer Network reported a rate of $40 \%$ in 1997-2002.25 The higher rate of immediate reconstruction reflects a shifting pattern of practice being led by specialized cancer centres in the US. In contrast, in Canada, only $1.1 \%$ of patients who had a mastectomy underwent immediate reconstruction in Nova Scotia in 2001. ${ }^{13}$ Current rates of immediate reconstruction in Ontario are unknown. For patients with in situ or early stage breast cancer, mastectomy with immediate breast reconstruction should be presented as an option along with breast-conservation therapy and mastectomy alone. Box 2 provides a fictional example of how to apply this review in clinical practice.

\section{Gaps in knowledge}

In Canada, little is known about the factors that influence the rate of breast reconstruction or the reasons for its underuse. The optimal rate of breast reconstruction is not currently known for any jurisdiction, and the absence of such a benchmark limits useful research in this area. However, given the broad array of factors that

\section{Box 2: Applying the results of this review in clinical practice} (fictional case)

A 60-year-old woman has a 2-cm invasive ductal carcinoma in the upper lateral quadrant of her right breast diagnosed by means of ultrasoundguided needle biopsy. There are no abnormalities in the other breast. She has no family history of breast cancer and is otherwise in good health. On physical examination, she has relatively symmetric B-cup breasts with minimal ptosis and a moderate amount of redundant lower abdominal tissue with a scar from a cesarean section.

Based on this clinical picture, this woman is a candidate for breastconservation therapy, mastectomy alone or skin-sparing mastectomy with immediate breast reconstruction. Her age is not a contraindication for breast reconstruction.

When discussing the surgical approach, her general surgeon points out that all three treatment options have equivalent survival rates. Because the decision will need to incorporate the patient's personal values, priorities and expectations, the surgeon spends some time discussing these with the patient. In addition, the surgeon offers an urgent referral to a reconstructive surgeon and a radiation oncologist to discuss the details of these treatment options.

The reconstructive surgeon explains that the patient is a candidate for either implant-based reconstruction or reconstruction with an autologous tissue flap using the deep inferior epigastric perforator flap composed of her redundant lower abdominal tissue. Either of these two options can be performed at the same time as the mastectomy.

After speaking with the reconstructive surgeon, the patient chooses to undergo skin-sparing mastectomy with immediate breast reconstruction using an autologous tissue flap. influence the rate of breast reconstruction and the low rate of breast reconstruction in Canada compared with other jurisdictions, it is unlikely that our current practice has achieved an optimal rate. An important step to address these knowledge gaps is to acquire a better understanding of the current rates and timing of breast reconstruction and the different factors that influence access to breast reconstruction in Canada.

\section{Limitations}

The rates of breast reconstruction discussed in this review were obtained from large administrative databases that may not accurately capture all important predictor variables. ${ }^{12,13-31}$ Clinical factors such as smoking, obesity and comorbidities were not routinely captured, and sociodemographic factors such as income were estimated from area code and census data. Coding misclassification (of breast cancer diagnosis and receipt of mastectomy with or without reconstruction) and the inability to capture outpatient mastectomy in some databases may misrepresent the true rates. The Surveillance, Epidemiology and End Results database (a frequent source of data for US studies) is the most representative registry for breast cancer in the US. However, it captures only reconstruction performed within the first course of treatment, thus leaving gaps in information for delayed reconstruction. National hospital-based studies as in Table 2 may not reflect patterns of care in the general population. Although patient and provider preferences undoubtedly influence the rate of reconstruction, the influence of such factors could not be assessed in most pattern-of-care studies and would be better addressed through qualitative or survey designs. ${ }^{33-37,39,40.44,45}$ The findings of our review are generalizable primarily to highincome, English-speaking countries because cultural differences in other parts of the world will have a tremendous impact on patients' decisions to undergo breast reconstruction.

Other factors such as public policy or the media may also influence the rates of breast reconstruction. For example, in 1998, the Women's Health and Cancer Rights Act was passed in the US in favour of mandatory insurance coverage for breast reconstruction. ${ }^{46}$ More recently, a bill in New York State was passed that mandated physicians to discuss the option of breast reconstruction with their patients before surgery for treatment of breast cancer. ${ }^{47}$ An external factor that may have had a negative influence on the rate of breast reconstruction after 1992 in the US is the moratorium by the Food and Drug Administration on the use of silicone implants. 
Women who underwent implant reconstruction before 1992 have expressed significant anxiety and regret about their decision. However, no study has specifically investigated the influence that this policy has had on rate of implant reconstruction. ${ }^{48}$

There is a paucity of useful guidelines in the US and Canada outlining the role of breast reconstruction in the management of breast cancer. It is plausible that the lack of formal guidelines may be an important barrier to reconstruction in Canada. As a result, the current approach to integrate breast reconstruction in the delivery of multidisciplinary care varies by institution. ${ }^{14,16}$ In contrast, in the United Kingdom, the Scottish Intercollegiate Guidelines Network and the National Institute for Health and Clinical Excellence have guidelines for breast cancer management, ${ }^{49,50}$ which recommend that general surgeons discuss breast reconstruction with their patients before oncologic surgery and offer immediate reconstruction when indicated.

\section{Summary}

The decision to proceed with breast reconstruction following mastectomy for breast cancer is a complex one. In general, we found that patientrelated factors such as increased age, nonwhite ethnic background, low income and nonurban location of residence, and cancer-related factors such as advanced stage and anticipated need for radiation therapy are associated with decreased rates of breast reconstruction..$^{12,13-27}$ Furthermore, modifiable barriers to breast reconstruction in Canada include knowledge gaps and misperceptions held by referring physicians and patients. ${ }^{40}$ Addressing these gaps in knowledge may increase the rate of breast reconstruction in Canada.

\section{References}

1. Cordeiro PG. Breast reconstruction after surgery for breast cancer. N Engl J Med 2008;359:1590-601.

2. Alderman AK, Wilkins EG, Kim HM, et al. Complications in postmastectomy breast reconstruction: two-year results of the Michigan breast reconstruction outcome study. Plast Reconstr Surg 2002;109:2265-74.

3. Cordeiro PG, McCarthy CM. A single surgeon's 12-year experience with tissue expander/implant breast reconstruction: part II. An analysis of long-term complications, aesthetic outcomes, and patient satisfaction. Plast Reconstr Surg 2006;118:832-9.

4. Cordeiro PG, McCarthy CM. A single surgeon's 12-year experience with tissue expander/implant breast reconstruction: part I. A prospective analysis of early complications. Plast Reconstr Surg 2006;118:825-31.

5. Mehrara BJ, Santoro TD, Arcilla E, et al. Complications after microvascular breast reconstruction: experience with 1195 flaps. Plast Reconstr Surg 2006;118:1100-9.

6. Disa JJ, McCarthy CM, Mehrara BJ, et al. Immediate latissimus dorsi/prosthetic breast reconstruction following salvage mastectomy after failed lumpectomy/irradiation. Plast Reconstr Surg 2008; 121:159e-64e.

7. Patani N, Devalia H, Anderson A, et al. Oncological safety and patient satisfaction with skin-sparing mastectomy and immediate breast reconstruction. Surg Oncol 2008;17:97-105.

8. Rozen WM, Ashton MW, Taylor GI. Defining the role for autologous breast reconstruction after mastectomy: social and onco- logic implications. Clin Breast Cancer 2008:8:134-42.

9. Elder EE, Brandberg Y, Bjorklund T, et al. Quality of life and patient satisfaction in breast cancer patients after immediate breast reconstruction: a prospective study. Breast 2005;14:201-8.

10. Zhong T, Hofer SO, McCready DR, et al. A comparison of surgical complications between immediate breast reconstruction and mastectomy: the impact on delivery of chemotherapy - an analysis of 391 procedures. Ann Surg Oncol 2011; July 27 [Epub ahead of print].

11. Alderman AK, Collins ED, Schott A, et al. The impact of breast reconstruction on the delivery of chemotherapy. Cancer 2010; 116:1791-800.

12. Morrow M, Scott SK, Menck HR, et al. Factors influencing the use of breast reconstruction postmastectomy: a National Cancer Database study. J Am Coll Surg 2001;192:1-8.

13. Barnsley GP, Sigurdson L, Kirkland S. Barriers to breast reconstruction after mastectomy in Nova Scotia. Can J Surg 2008; 51:447-52.

14. Baxter N, Goel V, Semple JL. Utilization and regional variation of breast reconstruction in Canada. Plast Reconstr Surg 2005; 115:338-9.

15. Polednak AP. Geographic variation in postmastectomy breast reconstruction rates. Plast Reconstr Surg 2000;106:298-301.

16. Alderman AK, McMahon L Jr, Wilkins EG. The national utilization of immediate and early delayed breast reconstruction and the effect of sociodemographic factors. Plast Reconstr Surg 2003;111:695-703.

17. Polednak AP. Postmastectomy breast reconstruction in Connecticut: trends and predictors. Plast Reconstr Surg 1999;104: 669-73.

18. Polednak AP. How frequent is postmastectomy breast reconstructive surgery? A study linking two statewide databases. Plast Reconstr Surg 2001;108:73-7.

19. Alderman AK, Wei Y, Birkmeyer JD. Use of breast reconstruction after mastectomy following the Women's Health and Cancer Rights Act. JAMA 2006;295:387-8.

20. Joslyn SA. Patterns of care for immediate and early delayed breast reconstruction following mastectomy. Plast Reconstr Surg 2005;115:1289-96.

21. Rosson GD, Singh NK, Ahuja N, et al. Multilevel analysis of the impact of community vs patient factors on access to immediate breast reconstruction following mastectomy in Maryland. Arch Surg 2008;143:1076-81.

22. Tseng WH, Stevenson TR, Canter RJ, et al. Sacramento area breast cancer epidemiology study: use of postmastectomy breast reconstruction along the rural-to-urban continuum. Plast Reconstr Surg 2010;126:1815-24

23. Kruper L, Holt A, Xu XX, et al. Disparities in reconstruction rates after mastectomy: patterns of care and factors associated with the use of breast reconstruction in southern California. Ann Surg Oncol. 2011;18:2158-65.

24. Desch CE, Penberthy LT, Hillner BE, et al. A sociodemographic and economic comparison of breast reconstruction, mastectomy, and conservative surgery. Surgery 1999;125:441-7.

25. Christian CK, Niland J, Edge SB, et al. A multi-institutional analysis of the socioeconomic determinants of breast reconstruction. Ann Surg 2006;243:241-9.

26. Tseng JF, Kronowitz SJ, Sun CC, et al. The effect of ethnicity on immediate reconstruction rates after mastectomy for breast cancer. Cancer 2004;101:1514-23.

27. Reuben BC, Manwaring J, Neumayer LA. Recent trends and predictors in immediate breast reconstruction after mastectomy in the United States. Am J Surg 2009;198:237-43.

28. Hall SE, Holman CDJ. Inequalities in breast cancer reconstructive surgery according to social and locational status in Western Australia. Eur J Surg Oncol 2003;29:519-25.

29. Hvilsom GB, Holmich LR, Frederiksen K, et al. Socioeconomic position and breast reconstruction in Danish women. Acta Oncol 2011;50:265-73.

30. Jeevan R, Cromwell DA, Browne JP, et al. Regional variation in use of immediate breast reconstruction after mastectomy for breast cancer in England. Eur J Surg Oncol 2010;36:750-5.

31. Yu KD, Di GH, Wu J, et al. Development and trends of surgical modalities for breast cancer in China: a review of 16-year data. Ann Surg Oncol 2007; 14:2502-9.

32. August DA, Wilkins E, Rea T. Breast reconstruction in older women. Surgery 1994;115:663-8.

33. Alderman AK, Hawley ST, Janz NK, et al. Racial and ethnic disparities in the use of postmastectomy breast reconstruction: results from a population-based study. J Clin Oncol 2009;27: 5325-30.

34. Morrow M, Mujahid M, Lantz PM, et al. Correlates of breast reconstruction. Cancer 2005;104:2340-6.

35. Handel N, Silverstein MJ, Waisman E, et al. Reasons why mas- 
tectomy patients do not have breast reconstruction. Plast Reconstr Surg 1990;86:1118-22.

36. Greenberg CC, Schneider EC, Lipsitz SR, et al. Do variations in provider discussions explain socioeconomic disparities in postmastectomy breast reconstruction? J Am Coll Surg 2008;206:605-15.

37. Alderman AK, Hawley ST, Waljee J, et al. Correlates of referral practices of general surgeons to plastic surgeons for mastectomy reconstruction. Cancer 2007;109:1715-20.

38. Alderman AK, Hawley ST, Morrow M, et al. Receipt of delayed breast reconstruction after mastectomy: Do women revisit the decision? Ann Surg Oncol 2011;18:1748-56.

39. Alderman AK, Hawley ST, Waljee J, et al. Understanding the impact of breast reconstruction on the surgical decision-making process for breast cancer. Cancer 2008;112:489-94.

40. Wanzel KR, Brown MH, Anastakis DJ, et al. Reconstructive breast surgery: referring physician knowledge and learning needs. Plast Reconstr Surg 2002;110:1441-50.

41. Atisha D, Alderman AK, Lowery JC, et al. Prospective analysis of long-term psychosocial outcomes in breast reconstruction: two-year postoperative results from the Michigan Breast Reconstruction Outcomes Study. Ann Surg 2008;247:1019-28.

42. Wilkins EG, Cederna PS, Lowery JC, et al. Prospective analysis of psychosocial outcomes in breast reconstruction: one-year postoperative results from the Michigan Breast Reconstruction Outcome Study. Plast Reconstr Surg 2000;106:1014-25.

43. Lester LJ. A critical viewpoint by a general surgeon toward reconstructive surgery after mastectomy. Clin Plast Surg 1979;6:15-7.

44. Guidance on cancer services. Improving outcomes in breast cancer - manual update. London (UK): National Institute for Clinical Excellence; 2002. Available: www.nice.org.uk/nicemedia /pdf/Improving_outcomes_breastcancer_manual.pdf (accessed 2011 Aug. 27).

45. Management of breast cancer in women. A national clinical guideline. Edinburgh (UK): Scottish Intercollegiate Guidelines Network; 2005. Available: www.sign.ac.uk/pdf/sign84.pdf (accessed 2011 Aug. 27)

46. Your rights after a mastectomy. Women's Health and Cancer Rights Act of 1998. Washington (DC): US Department of Labor;
Available: www.dol.gov/ebsa/Publications/whcra.html (accessed 2011 Feb. 28)

47. Hartocollis A. Before breast is removed, a discussion on options. The New York Times; 2010 Aug. 18. Available: www.nytimes .com/2010/08/19/nyregion/19surgery.html?_r=1\&scp=1\&sq=before $\% 20$ the $\% 20$ breast $\% 20$ is $\% 20$ removed, $\% 20$ a\%20discussion $\% 20$ on\%20options\&st=cse (accessed 2011 Mar. 22).

48. Winer EP, Fee-Fulkerson K, Fulkerson CC, et al. Silicone controversy: a survey of women with breast cancer and silicone implants. J Natl Cancer Inst 1993;85:1407-11.

49. Guidance on cancer services. Improving outcomes in breast cancer: manual update. England: National Institute for Clinical Excellence; 2002. Available: www.nice.org.uk/nicemedia/pdf /Improving_outcomes_breastcancer_manual.pdf (accessed 2011 Aug. 27).

50. Management of breast cancer in women. A national clinical guideline. Scotland: Scottish Intercollegiate Guidelines Network; 2005. Available: www.sign.ac.uk/pdf/sign84.pdf (accessed 2011 Aug. 27).

Affiliations: From the Division of Plastic and Reconstructive Surgery (Platt, Zhong), Department of Surgery and Surgical Oncology, University Health Network, University of Toronto, Toronto, Ont.; the Department of Surgery and Keenan Research Centre (Baxter), Li Ka Shing Knowledge Institute, St. Michael's Hospital, University of Toronto, Toronto, Ont.; and the Department of Health Policy, Management and Evaluation (Baxter), University of Toronto, Toronto, Ont.

Contributors: All of the authors contributed to the conception and design of the review and drafting and revising the article for important intellectual content. All of the authors approved the final version submitted for publication.

Acknowledgements: Dr. Baxter holds the Cancer Care Ontario Health Services Research Chair and an Early Researchers Award from the Ontario Ministry of Research and Innovation.

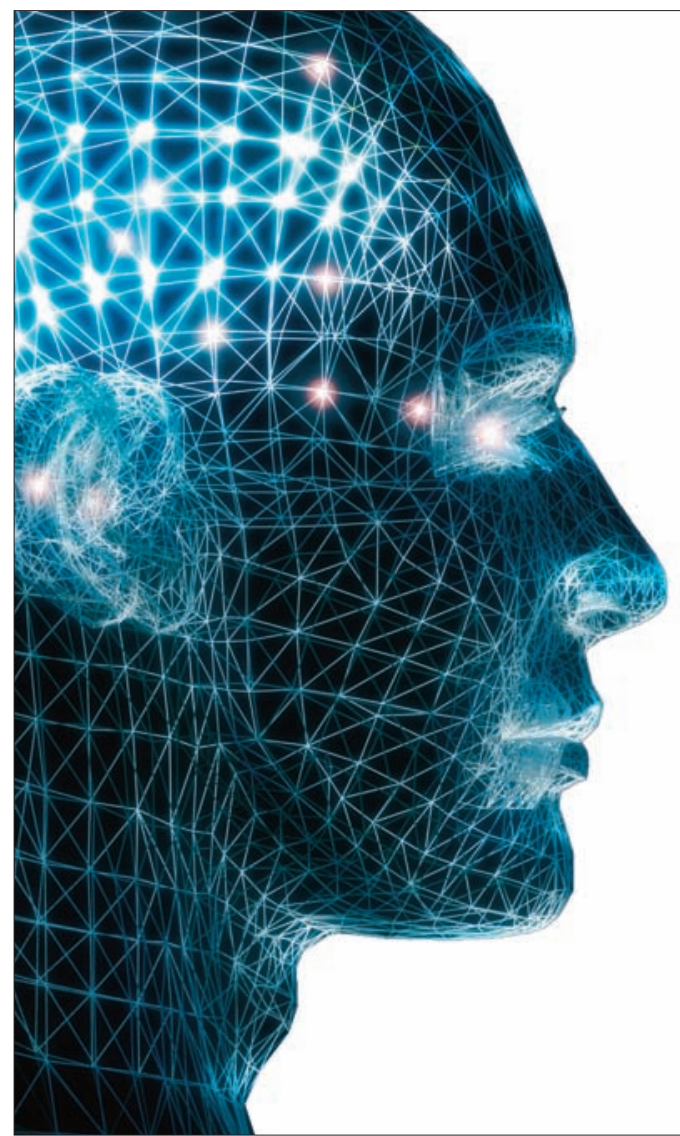

\title{
Be one of the first to know!
}

\author{
And sign up for Weekly Alerts of new content \\ posted on cmaj.ca
}

Don't miss out on online-only news and research articles that you won't see in print.

Go to www.cmaj.ca/cgi/alerts/etoc to sign up!

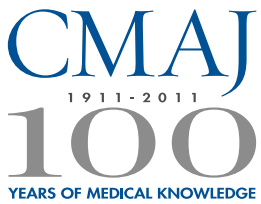

